\title{
New furoisocoumarins and isocoumarins from the mangrove endophytic fungus Aspergillus sp. 085242
}

\author{
Ze'en Xiao ${ }^{\ddagger 1,2}$, Senhua Chen ${ }^{\ddagger 1}$, Runlin Cai ${ }^{1}$, Shao'e Lin ${ }^{1}$, Kui Hong ${ }^{*}$ and Zhigang She ${ }^{* 1}$
}

\section{Full Research Paper}

\section{Address:}

${ }^{1}$ School of Chemistry and Chemical Engineering, Sun Yat-Sen University, No. 135 of Xingang West Road, Guangzhou, 510275, China, ${ }^{2}$ Shenzhen Academy of Metrology and Quality Inspection, No. 144 of Minkan Road, Minzhi Street, Longhua District, Shenzhen, 518102, China and ${ }^{3}$ Key Laboratory of Combinatorial Biosynthesis and Drug Discovery, Ministry of Education of China, School of Pharmaceutical Sciences, Wuhan University, Wuhan, 430071, China

Email:

Kui Hong ${ }^{*}$ - kuihong31@gmail.com;

Zhigang She* - cesshzhg@mail.sysu.edu.cn

* Corresponding author $\ddagger$ Equal contributors

Keywords:

a-glucosidase; Aspergillus; DPPH; furoisocoumarin; isocoumarin
Beilstein J. Org. Chem. 2016, 12, 2077-2085.

doi:10.3762/bjoc.12.196

Received: 17 July 2016

Accepted: 08 September 2016

Published: 23 September 2016

Associate Editor: J. S. Dickschat

(C) 2016 Xiao et al.; licensee Beilstein-Institut.

License and terms: see end of document.

\section{Abstract}

The chemical investigation of the mangrove endophytic fungus Aspergillus sp. 085242 afforded eight isocoumarin derivatives 1-8 and one isoquinoline 9. Asperisocoumarins A and B (1 and 2) were new furoisocoumarins, and asperisocoumarins E and F (5 and 6) were new isocoumarins. Their structures were established by analysis of their spectroscopic data and the absolute configuration of compound 2 was unambiguously determined by X-ray structure analysis and ECD calculation. Moreover, the absolute configurations of compounds 3-5 were assigned by comparison of their ECD spectra with isocoumarins described in the literature. Asperisocoumarins $\mathrm{C}$ and D (3 and $\mathbf{4}$ ) were fully characterized spectroscopically and isolated from a natural source for the first time. Asperisocoumarins A-D (1-4) related to the class of furo[3,2- $h$ ]isocoumarins are rarely occurring in natural sources. Compounds $\mathbf{2}, \mathbf{5}$, and 6 showed moderate $\alpha$-glucosidase inhibitory activity with $\mathrm{IC}_{50}$ of $87.8,52.3$, and $95.6 \mu \mathrm{M}$, respectively. In addition, compounds 1 and 3 exhibited weak radical scavenging activity with $\mathrm{EC}_{50}$ values of 125 and $138 \mu \mathrm{M}$, respectively.

\section{Introduction}

Isocoumarins are an important group of natural products with diverse structural features and interesting biological activities. They have been widely isolated from fungi, lichens, bacteria, plants, and insects [1,2]. Furoisocoumarins combining a furan ring and an isocoumarin moiety are divided into two subclasses depending on their fusion type: linear furo[2,3-g]isocoumarins and angular type furo[3,2- $h]$ isocoumarins. The linear furo[2,3$g]$ isocoumarins are relatively common in nature and coriandrin $[3,4]$, dihydrocoriandrin $[3,4]$, coriandrone $\mathrm{C}[5]$, and coriandrone E [5] are a few examples. However, an angular-type 
furo[3,2- $h]$ isocoumarin has up to date only been once reported from a natural source: Coriandrone A isolated from the aerial parts of Coriandrum sativum [6] and other furo[3,2- $h]$ isocoumarins have been reported as synthetic products [7-9].

In the last decade, our research group has been devoted to finding novel bioactive compounds from mangrove endophytic fungi derived from the South China Sea [10-15]. In a previous study, a chemical investigation of the endophytic fungal strain Aspergillus sp. 085242 allowed us to identify two novel sesquiterpenoids, asperterpenols A and B with an unusual 5/8/6/6 tetracyclic ring skeleton [15]. The unique structures of these sesquiterpenoids encouraged us to further study this fungal strain and continuous chemical investigation of it led to the isolation of two new furo[3,2- $h$ ] isocoumarins, asperisocoumarins $\mathrm{A}$ and $\mathrm{B}$ (1 and $\mathbf{2}$ ) and two new isocoumarins, asperisocoumarins $\mathrm{E}$ and $\mathrm{F}$ (5 and $\mathbf{6}$ ), together with five known compounds $(3,4,7-9)$ (Figure 1). Details of the isolation, structure elucidation, and biological activity of these compounds are reported herein.

\section{Results and Discussion}

The mangrove endophytic fungus Aspergillus sp. 085242 was cultured on solid rice medium with saline water for four weeks. The $\mathrm{MeOH}$ extract of the fermentation was fractionated by repeated silica gel chromatography and Sephadex LH-20 column chromatography to yield compounds $\mathbf{1 - 9}$.

Compound 1 was obtained as pale yellow crystal. Its molecular formula was established as $\mathrm{C}_{15} \mathrm{H}_{12} \mathrm{O}_{4}$ on the basis of HREIMS
( $m / z$ 256.0729, calcd for $\mathrm{C}_{15} \mathrm{H}_{12} \mathrm{O}_{4}, 256.0730$ ) and NMR data, implying ten degrees of unsaturation. The IR spectrum displayed intense absorption bands at 1737 and $1695 \mathrm{~cm}^{-1}$ indicating the presence of two carbonyl functionalities. The ${ }^{1} \mathrm{H}$ NMR data (Table 1) showed two aromatic AB spin system protons $\delta_{\mathrm{H}} 7.92(1 \mathrm{H}, \mathrm{d}, J=8.0 \mathrm{~Hz}, \mathrm{H}-4)$ and $\delta_{\mathrm{H}} 7.01(1 \mathrm{H}, \mathrm{d}, J=8.0 \mathrm{~Hz}$, $\mathrm{H}-5)$, one olefinic proton $\delta_{\mathrm{H}} 6.30(1 \mathrm{H}, \mathrm{s}, \mathrm{H}-6)$, and three methyl groups $\delta_{\mathrm{H}} 2.39(3 \mathrm{H}, \mathrm{s}, \mathrm{H}-13), \delta_{\mathrm{H}} 2.32(3 \mathrm{H}, \mathrm{s}, \mathrm{H}-10)$, and $\delta_{\mathrm{H}}$ $2.24(3 \mathrm{H}, \mathrm{s}, \mathrm{H}-12) .{ }^{13} \mathrm{C}$ and DEPT NMR spectra of 1 revealed the resonance of two carbonyl, six aromatic, four olefinic, and three methyl carbons. Key HMBC correlations (Figure 2) from H-10 to C-6 and C-7, H-6 to C-5, C-5a, and C-9a, H-4 to C-3a, $\mathrm{C}-5 \mathrm{a}$, and $\mathrm{C}-9 \mathrm{~b}$, and the upfield appearance of carbonyl group C-9 $\left(\delta_{C} 158.2\right)$ established a 3a,9b-disubstituted 7-methylisocoumarin unit. A 2-oxy-3-methyl-2-butenoyl moiety was assigned by the HMBC correlations of two methyl protons $\mathrm{H}-12$ and $\mathrm{H}-13$ to $\mathrm{C}-2, \mathrm{C}-3$, and $\mathrm{C}-11$, as well as the chemical shifts of these carbons. This moiety connected to the aromatic ring at C-3a was supported by the HMBC correlations of $\mathrm{H}-4$ with $\mathrm{C}-3$. An ether linkage between $\mathrm{C}-2$ and $\mathrm{C}-9 \mathrm{~b}$ was fused as a 3-oxobenzofuran unit according to the chemical shifts of $\mathrm{C}-2$ $\left(\delta_{\mathrm{C}} 145.7\right)$ and $\mathrm{C}-9 \mathrm{~b}\left(\delta_{\mathrm{C}} 165.1\right)$ as well as the required degrees of unsaturation. Thus, the structure of $\mathbf{1}$ was identified as 7-methyl-2-(propan-2-ylidene)- $9 H$-furo[3,2- $h$ ] isochromene3,9(2H)-dione, named asperisocoumarin A.

Compound 2 was obtained as colorless crystals, and analyzed for the molecular formula $\mathrm{C}_{15} \mathrm{H}_{18} \mathrm{O}_{4}$ by interpretation of HREIMS ( $m / z$ 262.1201, calcd for $\left.\mathrm{C}_{15} \mathrm{H}_{18} \mathrm{O}_{4}, 262.1200\right)$. The IR spectrum revealed the presence of an additional hydroxy<smiles>CC(C)=C1Oc2c(ccc3cc(C)oc(=O)c23)C1=O</smiles><smiles>CC1Cc2ccc(C(=O)C(=O)C(C)C)c(O)c2C(=O)O1</smiles>

5<smiles>COC1(C)Cc2ccc3c(c2CO1)OC(=C(C)C)C3=O</smiles><smiles>CC1Cc2ccc3c(c2C(=O)O1)O[C@H](C(C)C)[C@@H]3O</smiles>

2<smiles>CC(C)c1cc2ccc3c(c2o1)C(=O)O[C@H](C)C3</smiles>

3<smiles>CC(C)=C1Oc2c(ccc3c2C(=O)OC(C)C3)C1=O</smiles>

4<smiles>COc1cc2c(c(O)c1COCc1c(OC)cc3c(c1O)C(=O)OCC3)C(=O)OCC2</smiles>

6<smiles>CC(C)=C1Oc2c(ccc3cc(C)ncc23)C1=O</smiles>

Figure 1: The structure of compounds 1-9. 


\begin{tabular}{|c|c|c|c|c|c|c|c|c|}
\hline \multirow{2}{*}{ No. } & \multicolumn{2}{|l|}{1} & \multicolumn{2}{|l|}{2} & \multicolumn{2}{|l|}{3} & \multicolumn{2}{|l|}{4} \\
\hline & $\delta_{C}$ & $\delta_{\mathrm{H}}(\mathrm{J}$ in $\mathrm{Hz})$ & $\delta_{C}$ & $\delta_{\mathrm{H}}(\mathrm{J}$ in $\mathrm{Hz})$ & $\delta_{C}$ & $\delta_{\mathrm{H}}(\mathrm{J}$ in $\mathrm{Hz})$ & $\delta_{C}$ & $\delta_{\mathrm{H}}(\mathrm{J}$ in $\mathrm{Hz})$ \\
\hline 2 & 145.7, C & & $94.5, \mathrm{CH}$ & $4.17, \mathrm{dd}(5.5,10.2)$ & 167.2, C & & 145.3, C & \\
\hline 3 & 181.6, C & & $71.0, \mathrm{CH}$ & $5.09, d(5.5)$ & $99.6, \mathrm{CH}$ & $6.39, \mathrm{~d}(0.9)$ & 182.3, C & \\
\hline 3a & $123.1, \mathrm{C}$ & & $131.2, \mathrm{C}$ & & $130.1, \mathrm{C}$ & & 124.6, C & \\
\hline 4 & $130.3, \mathrm{CH}$ & $7.92, d(8.0)$ & $130.9, \mathrm{CH}$ & $7.53, \mathrm{~d}(7.5)$ & $125.8, \mathrm{CH}$ & $7.61, d(6.6)$ & $129.4, \mathrm{CH}$ & $7.88, d(7.7)$ \\
\hline 5 & $119.1, \mathrm{CH}$ & $7.01, d(8.0)$ & 119.6, CH & $6.76, d(7.5)$ & $121.5, \mathrm{CH}$ & $7.03, \mathrm{~d}(6.6)$ & $121.5, \mathrm{CH}$ & $7.01, d(7.7)$ \\
\hline $5 a$ & $145.7, \mathrm{C}$ & & $142.3, \mathrm{C}$ & & $135.3, \mathrm{C}$ & & $148.4, \mathrm{C}$ & \\
\hline 6 & $104.2, \mathrm{CH}$ & $6.30, \mathrm{~s}$ & $35.3, \mathrm{CH}_{2}$ & $2.90, \mathrm{~d}(8.4) ; 2.89, \mathrm{~d}(5.4)$ & $35.3, \mathrm{CH}_{2}$ & $3.01, \mathrm{~m}$ & $36.0, \mathrm{CH}_{2}$ & $3.02, \mathrm{~m}$ \\
\hline 7 & $159.0, \mathrm{C}$ & & $74.6, \mathrm{CH}$ & $4.61, \mathrm{~m}$ & $75.4, \mathrm{CH}$ & $4.70, \mathrm{~m}$ & $74.7, \mathrm{CH}$ & $4.70, \mathrm{~m}$ \\
\hline 9 & 158.2, C & & $162.4, \mathrm{C}$ & & $162.8, \mathrm{C}$ & & $161.4, \mathrm{C}$ & \\
\hline $9 a$ & 105.7, C & & 109.3, C & & 109.9, C & & $110.9, \mathrm{C}$ & \\
\hline $9 b$ & $165.1, \mathrm{C}$ & & 161.6, C & & 153.8, C & & 164.3, C & \\
\hline 10 & $20.1, \mathrm{CH}_{3}$ & $2.32, \mathrm{~s}$ & $20.8, \mathrm{CH}_{3}$ & $1.43, d(6.3)$ & 21.3, $\mathrm{CH}_{3}$ & $1.54, d(6.4)$ & $20.8, \mathrm{CH}_{3}$ & $1.55, \mathrm{~d}(6.3)$ \\
\hline 11 & $135.3, \mathrm{C}$ & & $27.3, \mathrm{CH}$ & $2.31, \mathrm{~m}$ & $28.3, \mathrm{CH}$ & $3.20, \mathrm{~m}$ & $135.6, \mathrm{C}$ & \\
\hline 12 & $20.8, \mathrm{CH}_{3}$ & $2.24, \mathrm{~s}$ & $20.0, \mathrm{CH}_{3}$ & $1.29, d(6.6)$ & $21.0, \mathrm{CH}_{3}$ & $1.38, d(6.9)$ & 20.9, $\mathrm{CH}_{3}$ & $2.22, \mathrm{~s}$ \\
\hline 13 & 17.7, $\mathrm{CH}_{3}$ & $2.39, \mathrm{~s}$ & $19.4, \mathrm{CH}_{3}$ & $1.14, d(6.6)$ & $21.0, \mathrm{CH}_{3}$ & $1.37, \mathrm{~d}(6.9)$ & 17.8, $\mathrm{CH}_{3}$ & $2.39, \mathrm{~s}$ \\
\hline
\end{tabular}

${ }^{\mathrm{a} 1} \mathrm{H}(400 \mathrm{MHz})$ and ${ }^{13} \mathrm{C}(100 \mathrm{MHz})$ in $\mathrm{CDCl}_{3}$.
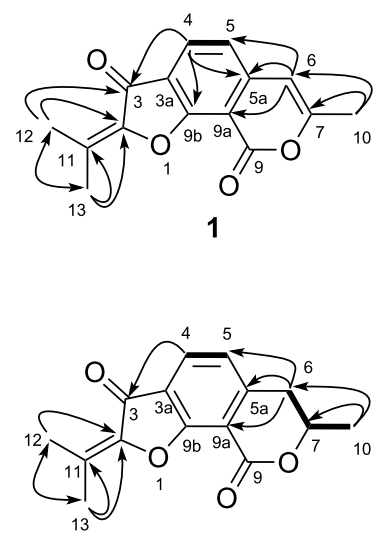

4
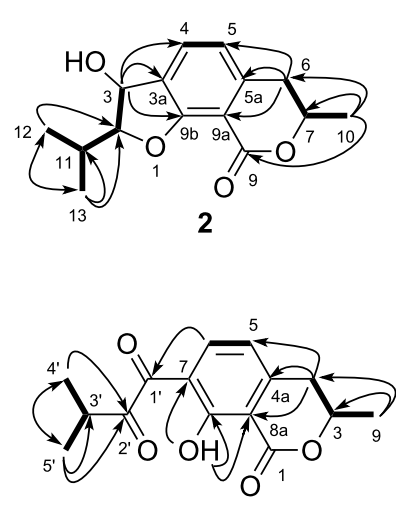

5

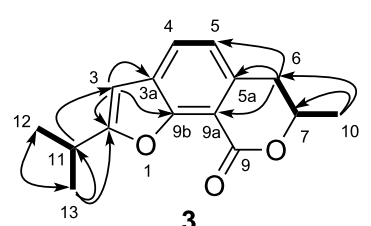

3

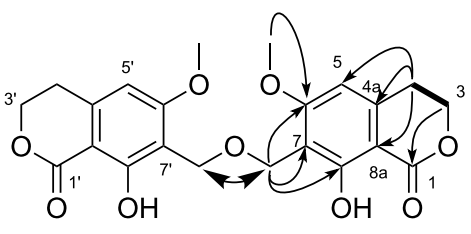

6

Figure 2: Key HMBC (arrows) and COSY (bold lines) correlations of compounds 1-6.

group at $3409 \mathrm{~cm}^{-1}$ and the absence of a carbonyl group at $1737 \mathrm{~cm}^{-1}$ in comparison with compound 1 . The ${ }^{1} \mathrm{H}$ NMR spectrum (Table 1) showed the signals corresponding to two ortho-coupled aromatic protons, four alkyl methine protons, one methylene, and three methyl groups. The ${ }^{13} \mathrm{C}$ NMR spectrum of 2 displayed the resonance of one carbonyl, six aromatic, four methine centers including three oxygenated, one methylene, and three methyl carbons. The above spectroscopic data suggested that compound $\mathbf{2}$ was a hexahydro-analogue of $\mathbf{1}$. This deduction was further evidenced by the HMBC correlations of $\mathrm{H}-10$ to C-9, C-7 and C-6, H-6 to C-5, C-5a and C-9a, and H-3 to $\mathrm{C}-3 \mathrm{a}, \mathrm{C}-4$ and $\mathrm{C}-9 \mathrm{~b}$, as well as the COSY correlations of $\mathrm{H}-2$ with $\mathrm{H}-3$ and $\mathrm{H}-11, \mathrm{H}-11$ with $\mathrm{H}-12$ and $\mathrm{H}-13, \mathrm{H}-4$ with $\mathrm{H}-5$, and H-7 with H-6 and H-10 (Figure 2). The relative configuration of compound 2 was determined by X-ray crystallographic analysis (Figure 3). The final refinement of the $\mathrm{CuK} \alpha$ data resulted in a Flack parameter of 0.12(16) and the Hooft parameter of $0.06(8)[16,17]$, which allowed the assignment of the absolute configuration of $\mathbf{2}$ as $(2 R, 3 R, 7 R)$ (Figure 3). Moreover, the predicted ECD curves of $\mathbf{2}$ and its relevant enantiomer were computed at the [B3LYP/6-31 G(2d,p)] level, and the experimental ECD curve of $\mathbf{2}$ agreed well with the predicted one (Figure 4), in accordance with the deduction from the X-ray crystallography analysis. Therefore, the structure of compound 2 was established as depicted in Figure 3 and named asperisocoumarin $\mathrm{B}$. 


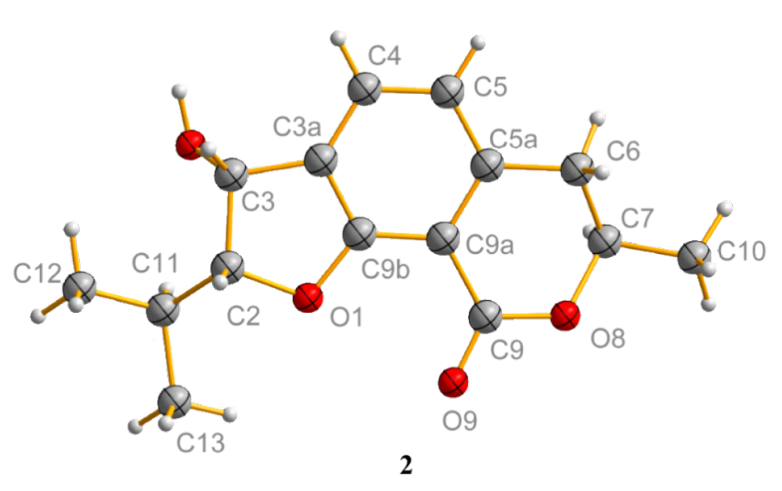

Figure 3: ORTEP structure of compound 2

Asperisocoumarin C (3) was obtained as a pale yellow crystalline solid and displayed an $[\mathrm{M}+\mathrm{H}]^{+}$ion in HRESIMS at $\mathrm{m} / \mathrm{z}$ 245.1174 , suggesting a molecular formula of $\mathrm{C}_{15} \mathrm{H}_{16} \mathrm{O}_{3}$. A careful comparison of its ${ }^{1} \mathrm{H}$ and ${ }^{13} \mathrm{C}$ NMR spectra (Table 1) with those of $\mathbf{2}$ indicated that compound $\mathbf{3}$ also shared the same isocoumarin skeleton as compound $\mathbf{2}$. The main differences were that an additional olefinic methine carbon at $\delta_{\mathrm{C}} 99.6$ and a quaternary carbon at $\delta_{\mathrm{C}} 167.2$ were observed, whereas two oxygenated methine carbons at $\delta_{\mathrm{C}} 94.5$ and 71.0 were absent in the spectrum of compound 3 . These differences were further supported by the HMBC correlations of olefinic proton $\mathrm{H}-3$ to C-2, C-3a and C-9b (Figure 2). By comparison of the ECD spectrum (Figure 5) and the optical rotation of 3 with data re- ported for dihydrocoumarins [18], it was possible to assign the absolute configuration of $\mathrm{C}-7$ as $R$. So, the structure of compound 3 was identified as $(R)$-2-isopropyl-7-methyl-6,7dihydro-9H-furo[3,2- $h]$ isochromen-9-one.

Asperisocoumarin D (4) was isolated as a white amorphous powder. Its molecular formula was determined as $\mathrm{C}_{15} \mathrm{H}_{14} \mathrm{O}_{4}$ by HREIMS ( $m / z 258.0888$, calcd for $\left.\mathrm{C}_{15} \mathrm{H}_{14} \mathrm{O}_{4}, 258.0887\right)$. The ${ }^{1} \mathrm{H}$ and ${ }^{13} \mathrm{C}$ NMR spectra of 4 were similar to those of asperisocoumarin A (1), except that the NMR resonances assigned to olefinic carbons C-6 and C-7 were replaced by $\mathrm{sp}^{3}$ hybridized methylene $\left(\delta_{\mathrm{C}} 36.0, \delta_{\mathrm{H}} 3.02\right)$ and methine $\left(\delta_{\mathrm{C}} 74.7, \delta_{\mathrm{H}} 4.70\right)$ signals. HMBC correlations from $\mathrm{H}-10\left(\delta_{\mathrm{H}} 2.12\right)$ to C-6 and C-7 and COSY correlations of H-7 with H-6 and H-10 further supported the above deduction (Figure 2). Finally, negative cotton effect $(\lambda=265 \mathrm{~nm}, \Delta \varepsilon=-15.10)$ observed in the ECD spectrum (Figure 5), allowed the definition of the absolute configuration at C-7 $(R)$ of compound 4 [18]. Thus, the structure of compound 4 was identified as $(R)$-2-isopropyl-7-methyl-6,7dihydro- $9 H$-furo[3,2- $h]$ isochromen-9-one.

Asperisocoumarin E (5) was obtained as a pale yellow powder and the molecular formula was deduced by HREIMS analysis as $\mathrm{C}_{15} \mathrm{H}_{16} \mathrm{O}_{5}\left(m / z 276.0092\right.$, calcd for $\left.\mathrm{C}_{15} \mathrm{H}_{16} \mathrm{O}_{5}, 276.0092\right)$, indicating eight degrees of unsaturation. The ${ }^{1} \mathrm{H}$ and ${ }^{13} \mathrm{C}$ NMR spectra of compound $\mathbf{5}$ were quite similar to those of $\mathbf{3}$ except for absence of an olefinic proton at H-3 and presence of two ad-

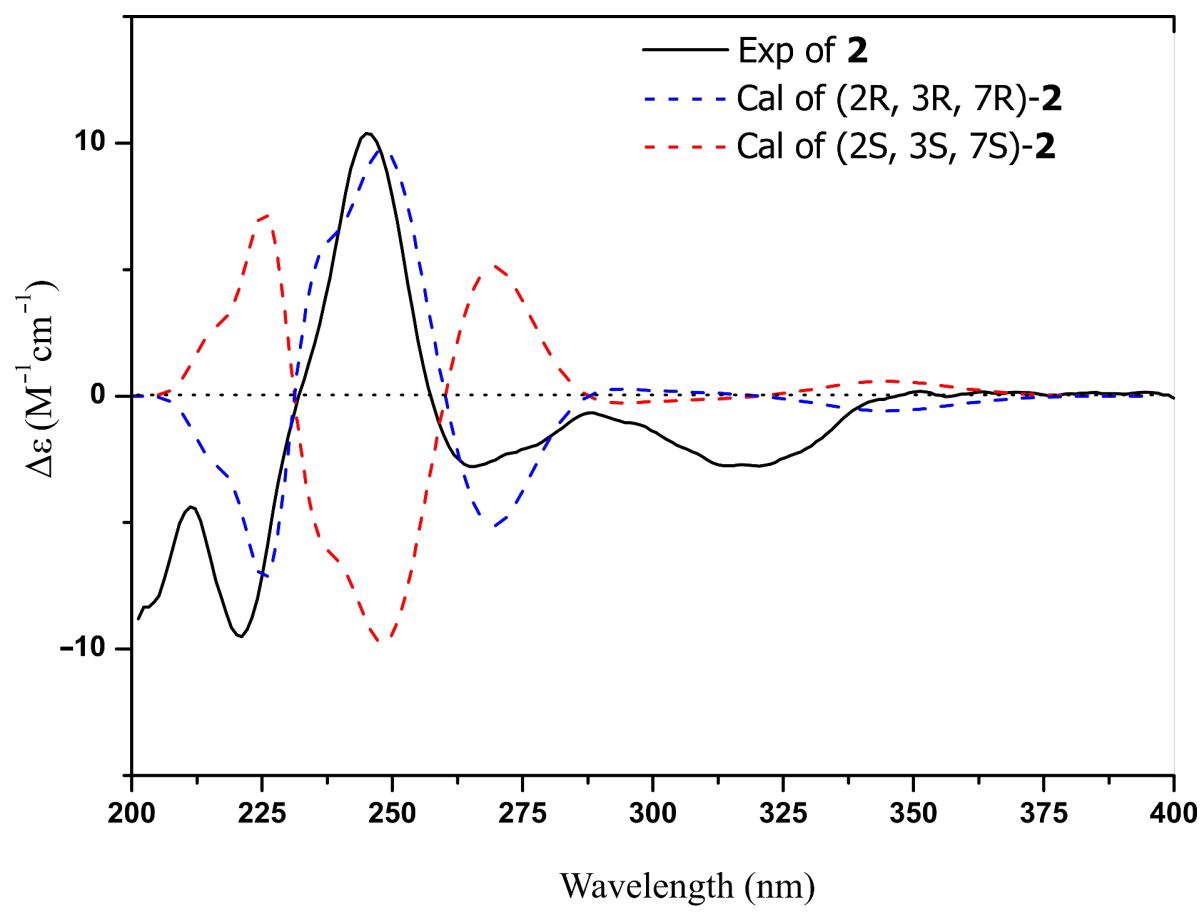

Figure 4: Comparison of the experimental and calculated ECD spectra of 2. 


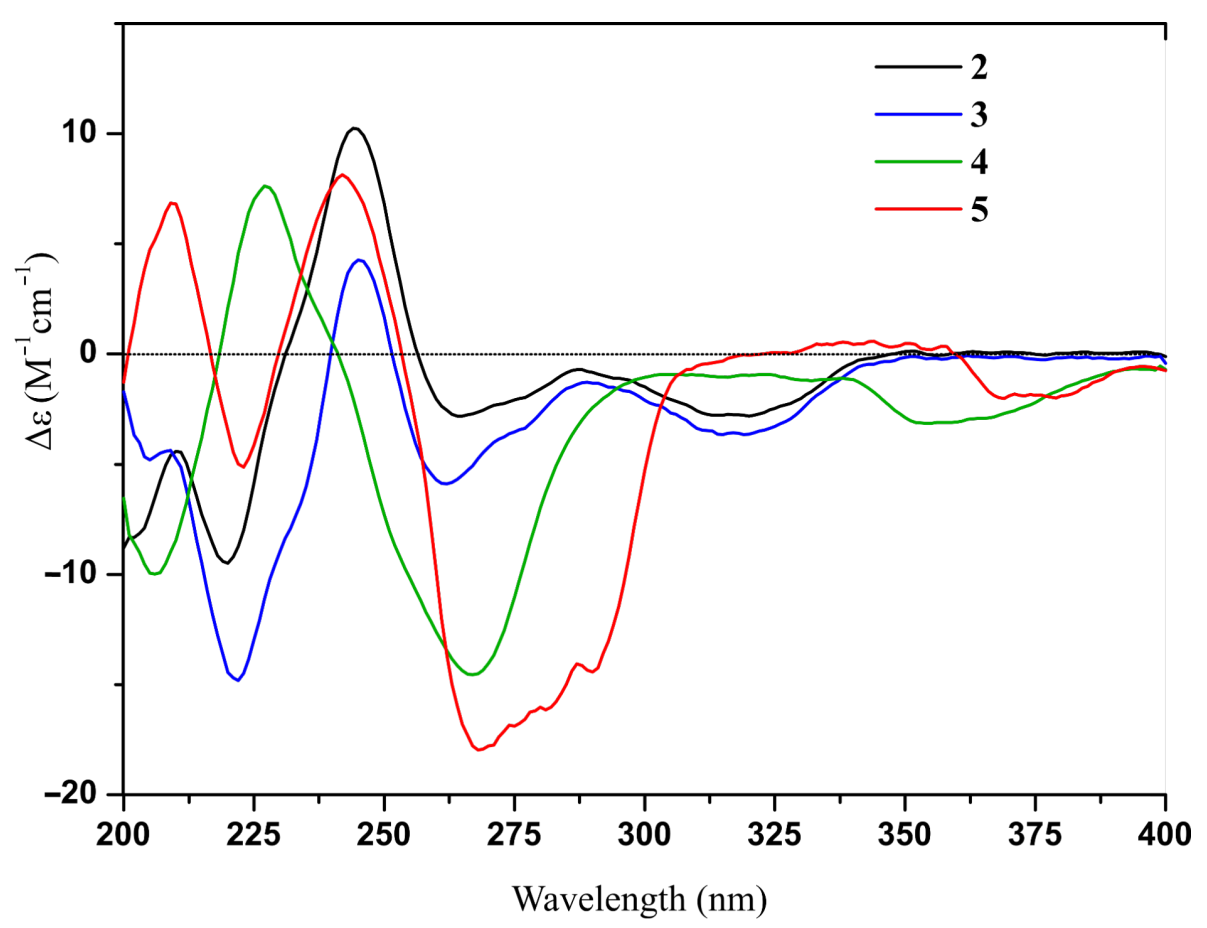

Figure 5: The experimental ECD spectra of 2-5.

ditional carbonyl carbons at C-1' $\left(\delta_{C} 206.2\right)$ and C-2' $\left(\delta_{C} 193.9\right)$, respectively (Table 2 ). This evidence suggested that compound 5 lacks a furan ring and is most likely be derived from the furan ring-opening and oxidation of compound $\mathbf{3}$, which was estab- lished by HMBC correlations of the aromatic proton $\mathrm{H}-6$ to C-1', two methyl protons $\mathrm{H}-4$ ' and $\mathrm{H}-5$ ' to $\mathrm{C}-2$ ', and chelated hydroxy proton $8-\mathrm{OH}$ to $\mathrm{C}-8, \mathrm{C}-7$, and $\mathrm{C}-8 \mathrm{a}$ (Figure 2). The negative circular dichroism at $265 \mathrm{~nm}$ (Figure 5) suggested $R$

\begin{tabular}{|c|c|c|c|c|c|}
\hline \multirow{2}{*}{ No. } & \multicolumn{2}{|l|}{5} & \multirow{2}{*}{ No. } & \multicolumn{2}{|l|}{6} \\
\hline & $\delta_{C}$ & $\delta_{\mathrm{H}}(\mathrm{J}$ in Hz) & & $\delta_{C}$ & $\delta_{\mathrm{H}}(J$ in $\mathrm{Hz})$ \\
\hline 1 & $169.4, \mathrm{C}$ & & $1 / 1^{\prime}$ & $169.7, \mathrm{C}$ & \\
\hline 3 & $76.0, \mathrm{CH}$ & $4.80, \mathrm{~m}$ & $3 / 3^{\prime}$ & $67.7, \mathrm{CH}_{2}$ & $4.51, \mathrm{t}(6.1)$ \\
\hline 4 & $34.8, \mathrm{CH}_{2}$ & $3.01, d(9.9), 3.03, d(5.0)$ & $4 / 4^{\prime}$ & 28.3, $\mathrm{CH}_{2}$ & $3.01, \mathrm{t}(6.1)$ \\
\hline $4 a$ & $146.4, \mathrm{C}$ & & $4 a / 4 a^{\prime}$ & 141.6, C & \\
\hline 5 & $118.8, \mathrm{CH}$ & $8.03, d(7.9)$ & $5 / 5^{\prime}$ & $101.4, \mathrm{CH}$ & $6.27, \mathrm{~s}$ \\
\hline 6 & 137.0, $\mathrm{CH}$ & $6.87, d(7.9)$ & $6 / 6^{\prime}$ & $164.6, \mathrm{C}$ & \\
\hline 7 & $121.9, \mathrm{C}$ & & $7 / 7^{\prime}$ & $112.8, \mathrm{C}$ & \\
\hline 8 & $162.4, \mathrm{C}$ & & $8 / 8^{\prime}$ & 162.7, C & \\
\hline $8 a$ & 109.3, C & & $8 a / 8 a^{\prime}$ & $102.4, \mathrm{C}$ & \\
\hline 9 & $20.7, \mathrm{CH}$ & $1.58, d(6.3)$ & 9/9' & $60.1, \mathrm{CH}_{2}$ & $4.67, \mathrm{~s}$ \\
\hline $1^{\prime}$ & 206.2, C & & $6 / 6^{\prime}-\mathrm{OCH}_{3}$ & $56.1, \mathrm{CH}_{3}$ & $3.87, \mathrm{~s}$ \\
\hline $2^{\prime}$ & 193.9, C & & $8 / 8 '-\mathrm{OH}$ & & $11.31, \mathrm{~s}$ \\
\hline $3^{\prime}$ & $36.6, \mathrm{CH}$ & $3.18, \mathrm{~m}$ & & & \\
\hline $4^{\prime}$ & $17.2, \mathrm{CH}_{3}$ & $1.29, d(7.0)$ & & & \\
\hline $5^{\prime}$ & 17.3, $\mathrm{CH}_{3}$ & $1.31, d(7.0)$ & & & \\
\hline $8-\mathrm{OH}$ & & $11.94, \mathrm{~s}$ & & & \\
\hline
\end{tabular}

${ }^{\mathrm{a}} \mathrm{H}(400 \mathrm{MHz})$ and ${ }^{13} \mathrm{C}(100 \mathrm{MHz})$ in $\mathrm{CDCl}_{3}$. 
configuration at $\mathrm{C}-3$, by comparison with data for isocoumarin derivatives described in the literature [13]. Thus, asperisocoumarin E (5) was elucidated as ( $R$ )-1-(8-hydroxy-3-methyl-1oxoisochroman-7-yl)-3-methylbutane-1,2-dione.

Asperisocoumarin F (6) was obtained as a white powder. The molecular formula of 6 was deduced as $\mathrm{C}_{22} \mathrm{H}_{22} \mathrm{O}_{9}$ from HRESIMS analysis $\left(m / z 429.1186[\mathrm{M}-\mathrm{H}]^{-}\right)$, implying 12 degrees of unsaturation. Its ${ }^{1} \mathrm{H}$ NMR spectrum resembled that of stellatin [13], except the absence of a hydroxy proton at $\delta_{\mathrm{H}}$ 2.24. In the ${ }^{13} \mathrm{C}$ NMR spectrum, the chemical shift value of the oxygenated methylene at C-9 was 3.9 ppm higher than that of stellatin [19]. At the same time, there was a strong HMBC correlation between H-9 and C-9' or H-9' and C-9. The above evidences allowed us to conclude that compound 6 was a polyether dimer of stellatin as shown in Figure 2.

In addition, the following known compounds were identified: ustusorane B (7) [20], penicisochroman A (8) [21], and TMC$120 \mathrm{~B}(9)$ [22], on the basis of the spectroscopic comparison with those reported in the literature as well as to the specific rotation. The structures of ustusorane B (7) and penicisochroman A (8) were analyzed by X-ray crystallography analysis (Figure 6) for the first time.

Numerous isocoumarin and 3,4-dihydroisocoumarin derivatives have been isolated from various natural sources [1]. However, the furo[3,2- $h]$ isocoumarin is a very uncommon class of isocoumarins and to date only a few members have been reported $[1,6]$. Asperisocoumarin A-D (1-4) were the second examples belonging to furo[3,2- $h]$ isocoumarins from natural sources. Asperisocoumarin B (2) shared the same planar structure as $(2 S, 3 S, 7 R)$-6,9-dihydro-3-hydroxy-7-methyl-2-(1methylethyl)-7H-furo[3,2- $h]$ [2] benzopyran-9 $(2 H)$-one, which was the intermediate of the syntheses of (-)-ustusorane $\mathrm{D}$ and (+)-penicisochroman B [8]. Asperisocoumarin C (3) and D (4) had the same structure as $(R)-2$-isopropyl-7-methyl-6,7-
dihydro-9H-furo[3,2- $h$ ] isochromen-9-one and $(R)$-7-methyl-2(propan-2-ylidene)-6,7-dihydro-9H-furo[3,2- $h]$ isochromene3,9-(2H)-dione, respectively. Both have been synthesized as intermediates during synthesis and structural characterization of natural benzofuranoids [9]. Asperisocoumarin E (5) containing an isopentenyl substituent with two adjacent carbonyl groups seems to be rare in natural isocoumarin derivatives and asperisocoumarin F (6) presents as a scaffold with an ether dimer of isocoumarin.

All isolates were evaluated for their $\alpha$-glucosidase inhibitory activity using clinical acarbose ( $\mathrm{IC}_{50}$ of $628.3 \mu \mathrm{M}$ ) as a positive control. Compounds $\mathbf{2}, \mathbf{5}$, and $\mathbf{6}$ showed moderate $\alpha$-glucosidase inhibitory activity with $\mathrm{IC}_{50}$ of $87.8,52.3$, and $95.6 \mu \mathrm{M}$, respectively. The other compounds were inactive $(>300 \mu \mathrm{M})$. Compounds 1-9 were also evaluated for antibacterial activities against Staphylococcus aureus, Staphylococcus epidermidis, Escherichia coli, Klebsiella pneumoniae, and Bacillus subtilis. None of the compounds was active at a concentration of $50 \mu \mathrm{g} / \mathrm{mL}$. In the free radical scavenging assay using 2,2diphenyl-1-picrylhydrazyl (DPPH), only compounds 1 and 3 exhibited weak activity with $\mathrm{EC}_{50}$ values of 125 and $130 \mu \mathrm{M}$, respectively (vitamin $\mathrm{C}$ was used as a positive control with $\left.\mathrm{EC}_{50}=35 \mu \mathrm{M}\right)$.

\section{Experimental}

General experimental procedures. Analogously as described in reference [12]. Melting points were determined with a FisherJohns hot-stage apparatus apparatus and are uncorrected. UV data were measured on a PERSEE TU-1900 spectrophotometer. Infrared spectra were recorded on a Nicolet Nexus 670 spectrophotometer using $\mathrm{KBr}$ discs. EIMS data were measured on a DSQ EI-mass spectrometer (Thermo, Shanghai, China) and HREIMS data were carried out on a DMAT95XP high-resolution mass spectrometer. ESIMS spectra were recorded on a Finnigan LCQ-DECA mass spectrometer and HRESIMS spectra were determined on a Shimadzu LCMS-IT-TOF mass spec-
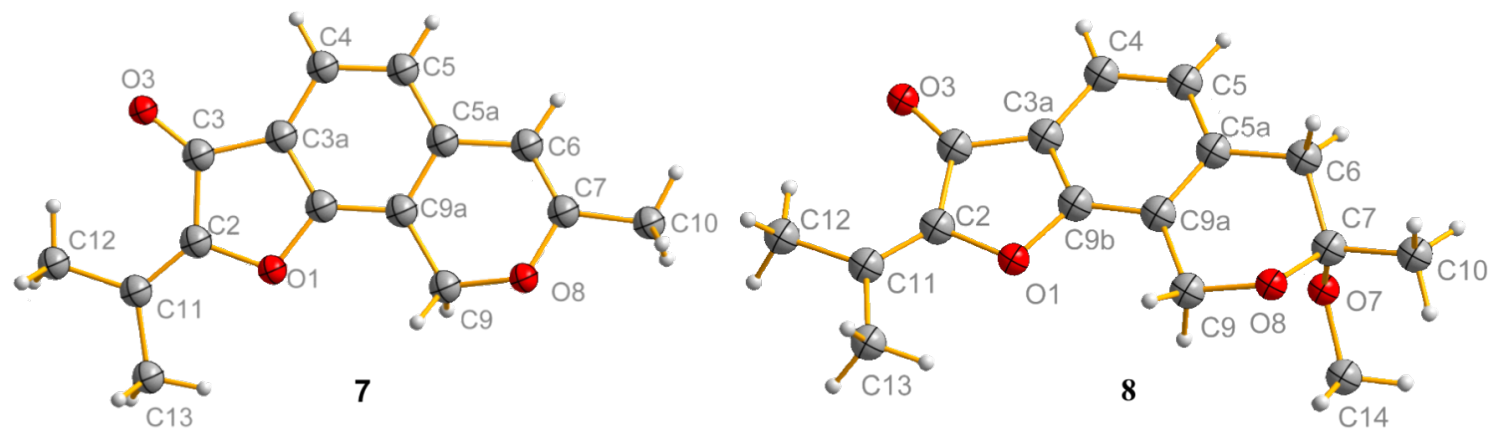

Figure 6: ORTEP structures of compound $\mathbf{7}$ and 8. 
trometer. 1D and 2D NMR spectra were carried out on Bruker Avance 400 spectrometer $\left({ }^{1} \mathrm{H} 400 \mathrm{MHz},{ }^{13} \mathrm{C} 100 \mathrm{MHz}\right)$. Chemical shifts $(\delta)$ are given in ppm with reference to the solvent signal $\left(\delta_{\mathrm{C}} 77.1 / \delta_{\mathrm{H}} 7.26\right.$ for $\left.\mathrm{CDCl}_{3}\right)$ and coupling constants $(J)$ are given in $\mathrm{Hz}$. ECD spectra were measured on a Chirascan CD spectrometer (Applied Photophysics, London, UK). Singlecrystal data were collected on an Agilent Gemini Ultra diffractometer (CuK $\alpha$ radiation). Silica gel (200-300 mesh, Qingdao Marine Chemical Factory) and Sephadex LH-20 (Amersham Pharmacia, Piscataway) were used for column chromatography (CC). Thin layer chromatography was performed on precoated silica gel plates (Qingdao Huang Hai Chemical Group Co., G60, F-254).

Fungal material. The fungus Aspergillus sp. 085242 was isolated from healthy roots of Acanthus ilicifolius, which were collected from the Shankou Mangrove National Nature Reserve in Guangxi Province, China. Fungal identification was carried out using a molecular biological protocol by DNA amplification and sequencing of the ITS region and the sequence data have been submitted to GenBank with accession no. KC816018.1. A BLAST search result indicated that the sequence was the most similar (99\%) to the sequence of Aspergillus sp. (compared to KP059102.1 and KJ567455.1). A voucher strain is deposited in the China Center for Type Culture Collection under patent depository number CCTCC M 2013081.

Fermentation, extraction, and isolation. Analogously as described in reference [12] the fungus was grown on autoclaved rice solid substrate medium (thirty $500 \mathrm{~mL}$ Erlenmeyer flasks, each containing $50 \mathrm{~g}$ rice and $50 \mathrm{~mL} 3 \%$ of saline water) at room temperature under static conditions and daylight for 28 days. Following incubation, the mycelia and solid rice medium were extracted with $\mathrm{MeOH}$ three times. The extract was evaporated under reduced pressure to yield $41 \mathrm{~g}$ of residue. The residue was then divided into 20 fractions (Fr. 1-Fr. 20) by column chromatography on silica gel eluted by a gradient of petroleum ether/EtOAc from 1:0 to 0:1. Fr. 4 (309 mg) was applied to the Sephadex LH-20 CC $\left(\mathrm{CHCl}_{3} / \mathrm{MeOH}, \mathrm{v} / \mathrm{v}, 1: 1\right)$ to give subfraction Fr. 4.9, which was purified on silica gel (petroleum ether/EtOAc, v/v, 8:2) to yield 1 (2.8 mg). Fr. 6 (105 mg) was rechromatographed on silica gel (petroleum ether/EtOAc, $\mathrm{v} / \mathrm{v}, 8: 2$ ) to give subfraction Fr. 6.8, which was purified by Sephadex LH-20 CC $\left(\mathrm{CHCl}_{3} / \mathrm{MeOH}, \mathrm{v} / \mathrm{v}, 1: 1\right)$ to yield 7 $(2.3 \mathrm{mg})$ and 8 (2.1 mg). Fr. 7 (264 mg) was subsequently separated by Sephadex LH-20 CC eluted with $\left(\mathrm{CHCl}_{3} / \mathrm{MeOH}\right.$, v/v, 1:1) to give subfraction Fr. 7.9, which was purified on silica gel (petroleum ether/EtOAc, v/v, 7:3) to yield $2(5.4 \mathrm{mg})$ and 3 (2.5 mg), respectively. Fr. 9 was chromatographed on Sephadex $\mathrm{LH}-20 \mathrm{CC}\left(\mathrm{CHCl}_{3} / \mathrm{MeOH}, \mathrm{v} / \mathrm{v}, 1: 1\right)$ to give subfraction Fr. 9.7, which was purified using silica gel (petroleum ether/EtOAc, $\mathrm{v} / \mathrm{v}, 7: 3)$ to give $4(4.1 \mathrm{mg})$ and $\mathbf{5}(2.6 \mathrm{mg})$. Fr. $11(180 \mathrm{mg})$ was subsequently separated by Sephadex LH-20 CC eluted with $\mathrm{MeOH}$ to obtain $6(3.1 \mathrm{mg})$. Fr. 12 was chromatographed on silica gel (petroleum ether/EtOAc, v/v, 6:4) to produce 9 (5.2 mg).

Asperisocoumarin A (1): pale yellow crystals; mp 189.5-192.0 ${ }^{\circ} \mathrm{C}$; UV (MeOH) $\lambda_{\max }(\log \varepsilon): 240$ (4.25), 357 (3.56) nm; IR (KBr) $v_{\max }: 3074,2998,2904,1737,1695,1656$, 1606, 1576, 1458, 1343, 1265, 1164, $1078 \mathrm{~cm}^{-1}$; EIMS $(\mathrm{m} / \mathrm{z})$ : 256; HRMS-EI $(\mathrm{m} / z): \mathrm{C}_{15} \mathrm{H}_{12} \mathrm{O}_{4}$ calcd for 256.0730; found, 256.0729; ${ }^{1} \mathrm{H} \mathrm{NMR}\left(\mathrm{CDCl}_{3}, 400 \mathrm{MHz}\right)$ and ${ }^{13} \mathrm{C} \mathrm{NMR}\left(\mathrm{CDCl}_{3}\right.$, $100 \mathrm{MHz}$ ), see Table 1.

Asperisocoumarin B (2): colorless crystals; mp 179.4-181.4 ${ }^{\circ} \mathrm{C}$; $[\alpha]_{\mathrm{D}}{ }^{20}+25.3(c 0.02, \mathrm{MeOH}) ; \mathrm{UV}(\mathrm{MeOH}) \lambda_{\max }(\log \varepsilon): 220$ (4.83), 248 (4.25), 317 (3.56) nm; IR (KBr) $v_{\max }$ : 3391, 2973, 2935, 2868, 1691, 1610, 1451, 1383, 1175, $1054 \mathrm{~cm}^{-1}$; EIMS $(\mathrm{m} / \mathrm{z})$ : 262; HRMS-EI $(\mathrm{m} / \mathrm{z}): \mathrm{C}_{15} \mathrm{H}_{18} \mathrm{O}_{4}$ calcd for 262.1200; found, 262.1201; ${ }^{1} \mathrm{H} \mathrm{NMR}\left(\mathrm{CDCl}_{3}, 400 \mathrm{MHz}\right)$ and ${ }^{13} \mathrm{C} \mathrm{NMR}$ $\left(\mathrm{CDCl}_{3}, 100 \mathrm{MHz}\right)$, see Table 1 .

Asperisocoumarin C (3): pale yellow amorphous powder; $\mathrm{mp}$ 122.4-124.8 ${ }^{\circ} \mathrm{C} ;[\alpha]_{\mathrm{D}}{ }^{20}-78.9(c 0.02, \mathrm{MeOH}) ; \mathrm{UV}(\mathrm{MeOH})$ $\lambda_{\max }(\log \varepsilon): 221$ (4.85), 252 (4.26), 324 (3.54) nm; IR (KBr) $v_{\max }: 3391,2973,2935,2868,1691,1610,1451,1383,1175$, $1054 \mathrm{~cm}^{-1}$; EIMS $(\mathrm{m} / \mathrm{z})$ 244; HRMS-ESI $(\mathrm{m} / \mathrm{z}):[\mathrm{M}+\mathrm{H}]^{+}$calcd for $\mathrm{C}_{15} \mathrm{H}_{16} \mathrm{O}_{3}$, 245.1173; found, 245.1174; ${ }^{1} \mathrm{H} \mathrm{NMR}\left(\mathrm{CDCl}_{3}\right.$, $400 \mathrm{MHz})$ and ${ }^{13} \mathrm{C} \mathrm{NMR}\left(\mathrm{CDCl}_{3}, 100 \mathrm{MHz}\right)$, see Table 1.

Asperisocoumarin D (4): white amorphous powder; mp $182.2-184.4{ }^{\circ} \mathrm{C} ;[\alpha]_{\mathrm{D}}{ }^{20}-70(c 0.01, \mathrm{MeOH}) ; \mathrm{UV}(\mathrm{MeOH}) \lambda_{\max }$ ( $\log \varepsilon$ ): 222 (4.89), 249 (4.28), 319 (3.50) nm; IR (KBr) $v_{\max }$ : 3390, 2976, 2934, 2866, 1692, 1612, 1453, 1381, 1176, $1056 \mathrm{~cm}^{-1}$; EIMS $(\mathrm{m} / \mathrm{z}): 258$; HRMS-EI $(\mathrm{m} / \mathrm{z}): \mathrm{C}_{15} \mathrm{H}_{14} \mathrm{O}_{4}$ calcd for 258.0887; found, 258.0888; ${ }^{1} \mathrm{H} \mathrm{NMR}\left(\mathrm{CDCl}_{3}, 400 \mathrm{MHz}\right)$, see Table 1 .

Asperisocoumarin E (5): pale yellow crystals; mp $136.1-138.0{ }^{\circ} \mathrm{C} ;[\alpha]_{\mathrm{D}}{ }^{20}-78.6(c 0.02, \mathrm{MeOH}) ; \mathrm{UV}(\mathrm{MeOH})$ $\lambda_{\max }(\log \varepsilon): 220$ (4.84), 335 (3.56) nm; IR (KBr) $v_{\max }: 3376$, 2979, 1707, 1607, 1431, 1389, 1273, 1135, $806 \mathrm{~cm}^{-1}$; EIMS $(\mathrm{m} / \mathrm{z})$ : 276; HRMS-EI $(\mathrm{m} / \mathrm{z}): \mathrm{C}_{15} \mathrm{H}_{16} \mathrm{O}_{5}$ calcd for 276.0092; found, 276.0092; ( ${ }^{1} \mathrm{H} \mathrm{NMR}\left(\mathrm{CDCl}_{3}, 400 \mathrm{MHz}\right)$ and ${ }^{13} \mathrm{C} \mathrm{NMR}$ $\left(\mathrm{CDCl}_{3}, 100 \mathrm{MHz}\right)$, see Table 2.

Asperisocoumarin $\mathrm{F}(6)$ : white amorphous powder; $\mathrm{mp}$ 201.1-203.0 ${ }^{\circ} \mathrm{C}$; UV (MeOH) $\lambda_{\max }(\log \varepsilon): 268$ (4.64), 299 (3.36) nm; IR (KBr) $v_{\max }: 3476,2998,1670,1581,1369,1283$, $1125 \mathrm{~cm}^{-1}$; EIMS $(\mathrm{m} / \mathrm{z}): 430$; HRMS-ESI $(\mathrm{m} / \mathrm{z}):[\mathrm{M}-\mathrm{H}]^{-}$ 
calcd for $\mathrm{C}_{15} \mathrm{H}_{18} \mathrm{O}_{4}, 429.1186$; found, 429.1186; ${ }^{1} \mathrm{H}$ NMR $\left(\mathrm{CDCl}_{3}, 400 \mathrm{MHz}\right)$ and ${ }^{13} \mathrm{C} \mathrm{NMR}\left(\mathrm{CDCl}_{3}, 100 \mathrm{MHz}\right)$, see Table 2.

X-ray crystallographic analysis. Single crystal X-ray diffraction data were collected at $123 \mathrm{~K}$ on an Agilent Gemini Ultra diffractometer with $\mathrm{CuK} \alpha$ radiation $(\lambda=1.54178 \AA$ ). The structures were solved by direct methods (SHELXS-97) and refined using full-matrix least-squares difference Fourier techniques. Hydrogen atoms bonded to carbons were placed on the geometrically ideal positions by the "ride on" method. Hydrogen atoms bonded to oxygen were located by the difference Fourier method and were included in the calculation of structure factors with isotropic temperature factors. Crystallographic data for 2, 7 and 8 have been deposited with the Cambridge Crystallographic Data Centre. Copies of the data can be obtained, free of charge, on application to the Director, CCDC, 12 Union Road, Cambridge CB2 1EZ, UK (fax: 44-(0)1223-336033, or email: deposit@ccdc.cam.ac.uk).

Crystal data of 2: $\mathrm{C}_{15} \mathrm{H}_{18} \mathrm{O}_{4}, M \mathrm{r}=262.29$, monoclinic, $a=$ 16.4513(3) $\AA, b=11.2236(2) \AA, c=8.27930(10) \AA, \alpha=90.00$, $\beta=116.344, \gamma=90.00, V=1369.95(4) \AA^{3}$, space group $C 2, Z=$ $4, D_{\text {calcd }}=1.272 \mathrm{mg} / \mathrm{m}^{3}, \mu=0.754 \mathrm{~mm}^{-1}$, and $F(000)=560$. Crystal dimensions: $0.44 \times 0.41 \times 0.40 \mathrm{~mm}^{3}$. Independent reflections: $1987\left(R_{\text {int }}=0.0180\right)$. The final $R_{1}$ values were 0.0237, $\omega R_{2}=0.0614(\mathrm{I}>2 \sigma(\mathrm{I}))$. The goodness of fit on $F^{2}$ was 1.078. Flack parameter $=0.12$ (16). CCDC number: 1458037 .

Crystal data of 7: $\mathrm{C}_{15} \mathrm{H}_{14} \mathrm{O}_{3}, M \mathrm{r}=242.26$, monoclinic, $a=$ 7.6380(3) $\AA, b=13.8996(6) \AA, c=11.22829(4) \AA, \alpha=90.00$, $\beta=95.368(4), \gamma=90.00, V=1192.60(8) \AA^{3}$, space group $P 2_{1} / n, Z=4, D_{\text {calcd }}=1.349 \mathrm{mg} / \mathrm{m}^{3}, \mu=0.093 \mathrm{~mm}^{-1}$, and $F(000)=512$. Crystal dimensions: $0.42 \times 0.33 \times 0.23 \mathrm{~mm}^{3}$. Independent reflections: $2569\left(R_{\mathrm{int}}=0.0228\right)$. The final $R_{1}$ values were $0.0419, \omega R_{2}=0.0961(\mathrm{I}>2 \sigma(\mathrm{I}))$. The goodness of fit on $F^{2}$ was 1.037. Flack parameter $=0.09(10)$. CCDC number: 1458039 .

Crystal data of 8: $\mathrm{C}_{32} \mathrm{H}_{36} \mathrm{O}_{8}, M \mathrm{r}=548.60$, triclinic, $a=$ 6.5460(2) $\AA, b=8.6973(3) \AA, c=12.0611(4) \AA, \alpha=88.934(3)$, $\beta=85.192(3), \gamma=85.357(3), V=1369.95(4) \AA^{3}$, space group $P-1, Z=2, D_{\text {calcd }}=1.336 \mathrm{mg} / \mathrm{m}^{3}, \mu=0.782 \mathrm{~mm}^{-1}$, and $F(000)$ $=296$. Crystal dimensions: $0.42 \times 0.28 \times 0.23 \mathrm{~mm}^{3}$. Independent reflections: $2423\left(R_{\text {int }}=0.0263\right)$. The final $R_{1}$ values were $0.0350, \omega R_{2}=0.0899(\mathrm{I}>2 \sigma(\mathrm{I}))$. The goodness of fit on $F^{2}$ was 1.067. CCDC number: 1458040.

Calculation of ECD spectra. Molecular Merck force field (MMFF) and DFT/TD-DFT calculations were carried out with Spartan' 14 software (Wavefunction Inc., Irvine, CA, USA) and
Gaussian 09 program, respectively. Conformers within $10 \mathrm{kcal} / \mathrm{mol}$ energy window were generated and optimized using DFT calculations at B3LYP/6-31G(d) level. Conformers with Boltzmann distribution over $1 \%$ were chosen for ECD calculations in methanol at B31YP/6-311+g(2d,p) level. The IEF-PCM solvent model for $\mathrm{MeOH}$ was used. ECD spectra were generated using the program SpecDis 3.0 (University of Würzburg, Würzburg, Germany) and OriginPro 8.5 (OriginLab, Ltd., Northampton, MA, USA) from dipole-length rotational strengths by applying Gaussian band shapes with sigma = $0.30 \mathrm{eV}$ and $\mathrm{UV}$ shift $=+21 \mathrm{~nm}$. All calculations were performed with High-Performance Grid Computing Platform of Sun Yat-Sen University.

Biological assays. The assays for antibacterial [23] and $\alpha$-glucosidase inhibitory [23] were carried out as described previously.

The assay for DPPH radical scavenging activity was measured by a reported method [24,25], with slight modifications. Firstly, $180 \mu \mathrm{L}$ of DPPH $(150 \mu \mathrm{M}$ in $\mathrm{MeOH})$ and $20 \mu \mathrm{L}$ of a series of test compound solutions $(31.2,62.5,125,250,500 \mu \mathrm{M}$ in $\mathrm{MeOH})$ were mixed in each well of a 96-well microtiter plate. The reaction was measured by determination of the absorbance $\mathrm{A}_{\text {sample+DPPH }} \cdot$ using a microtiter plate reader at $490 \mathrm{~nm}$ after shaking for $30 \mathrm{~min}$ at room temperature in the dark. Twenty $\mu \mathrm{L}$ test samples of each concentration with $180 \mu \mathrm{L}$ of $\mathrm{MeOH}$ were used as the blank measurement for each tested compound, and the absorbance was recorded as $\mathrm{A}_{\text {sample }}$. The absorbance of the mixture of $20 \mu \mathrm{L}$ of $\mathrm{MeOH}$ and $180 \mu \mathrm{L}$ of $\mathrm{DPPH}$ was recorded as $\mathrm{A}_{\mathrm{DPPH}}$, and the absorbance of the $200 \mu \mathrm{L}$ of $\mathrm{MeOH}$ was measured as $A_{\text {blank. The natural antioxidant vitamin } C \text { was used }}$ as a positive control. Calculations of the DPPH' scavenging activity was performed according to the following equation: scavenging activity $(\%)=\left[1-\left(\mathrm{A}_{\text {sample+DPPH}}{ }^{-}-\mathrm{A}_{\text {sample }}\right) /\left(\mathrm{A}_{\mathrm{DPPH}}{ }^{--}\right.\right.$ $\left.\left.A_{\text {blank }}\right)\right] \times 100 \%$. All measurements were done in triplicate from two independent experiments. The reported $\mathrm{EC}_{50}$ was the average value of two independent experiments.

\section{Supporting Information}

\section{Supporting Information File 1}

1D and 2D NMR, HREIMS, and HRESIMS spectra of the new compounds.

[http://www.beilstein-journals.org/bjoc/content/ supplementary/1860-5397-12-196-S1.pdf]

\section{Acknowledgements}

We thank the National Natural Science Foundation of China (21472251, 41276146), the Science \& Technology Plan Project 
of Guangdong Province of China (2013B021100011), the Key project of Natural Science Foundation of Guangdong Province (2016A040403091), Special Financial Fund of Innovative Development of Marine Economic Demonstration Project (GD2012-D01-001), China's Marine Commonwealth Research Project (201305017) for generous support.

\section{References}

1. Saeed, A. Eur. J. Med. Chem. 2016, 30, 290-317. doi:10.1016/j.ejmech.2016.03.025

2. Hill, R. A. Prog. Chem. Org. Nat. Prod. 1986, 49, 1-78.

3. Ceska, O.; Chaudhary, S. K.; Warrington, P.; Ashwood-Smith, M. J.; Bushnell, G. W.; Poultont, G. A. Phytochemistry 1988, 27, 2083-2087. doi:10.1016/0031-9422(88)80101-8

4. Ashwood-Smith, M. J.; Warrington, P. J.; Jenkins, M.; Ceska, O.; Romaniuk, P. J. Photochem. Photobiol. 1989, 50, 745-751. doi:10.1111/j.1751-1097.1989.tb02905.x

5. Taniguchi, M.; Yanai, M.; Xiao, Y. Q.; Kido, T.-i; Baba, K. Phytochemistry 1996, 42, 843-846. doi:10.1016/0031-9422(95)00930-2

6. Baba, K.; Xiao, Y.-Q.; Taniguchi, M.; Ohishi, H.; Kozawa, M. Phytochemistry 1991, 30, 4143-4146. doi:10.1016/0031-9422(91)83482-Z

7. Saito, F.; Kuramochi, K.; Nakazaki, A.; Mizushina, Y.; Sugawara, F.; Kobayashi, S. Eur. J. Org. Chem. 2006, 21, 4796-4799. doi:10.1002/ejoc.200600702

8. Kuramochi, K.; Tsubaki, K.; Kuriyama, I.; Mizushina, Y.; Yoshida, H.; Takeuchi, T.; Kamisuki, S.; Sugawara, F.; Kobayashi, S. J. Nat. Prod. 2013, 76, 1737-1745. doi:10.1021/np400460m

9. Kuramochi, K.; Tsubaki, K. J. Nat. Prod. 2015, 78, 1056-1066. doi:10.1021/np5010483

10. Liu, Z.; Chen, Y.; Chen, S.; Liu, Y.; Lu, Y.; Chen, D.; Lin, Y.; Huang, X.; She, Z. Org. Lett. 2016, 18, 1406-1409. doi:10.1021/acs.orglett.6b00336

11. Liu, Y.; Yang, Q.; Xia, G.; Huang, H.; Li, H.; Ma, L.; Lu, Y.; He, L.; Xia, X.; She, Z. J. Nat. Prod. 2015, 78, 1816-1822. doi:10.1021/np500885f

12. Chen, S.; Liu, Z.; Liu, Y.; Lu, Y.; He, L.; She, Z. Beilstein J. Org. Chem. 2015, 11, 1187-1193. doi:10.3762/bjoc.11.133

13. Li, H.; Jiang, J.; Liu, Z.; Lin, S.; Xia, G.; Xia, X.; Ding, B.; He, L.; Lu, Y.; She, Z. J. Nat. Prod. 2014, 77, 800-806. doi:10.1021/np400880w

14. Huang, X.; Huang, H.; Li, H.; Sun, X.; Huang, H.; Lu, Y.; Lin, Y.; Long, Y.; She, Z. Org. Lett. 2013, 15, 721-723. doi:10.1021/ol303549c

15. Xiao, Z.; Huang, H.; Shao, C.; Xia, X.; Ma, L.; Huang, X.; Lu, Y.; Lin, Y.; Long, Y.; She, Z. Org. Lett. 2013, 15, 2522-2525. doi:10.1021/ol401005j

16. Flack, H. D. Acta Crystallogr., Sect. A: Found. Crystallogr. 1983, A39, 876-881. doi:10.1107/S0108767383001762

17. Flack, H. D.; Bernardinelli, G. Chirality 2008, 20, 681-690. doi:10.1002/chir.20473

18. Choukchou-Braham, N.; Asakawa, Y.; Lepoittevin, J. P. Tetrahedron Lett. 1994, 35, 3949-3952. doi:10.1016/S0040-4039(00)76710-4

19. Simpson, T. J. J. Chem. Soc., Chem. Commun. 1978, 627-628. doi:10.1039/C39780000627

20. Lu, Z.; Wang, Y.; Miao, C.; Liu, P.; Hong, K.; Zhu, W. J. Nat. Prod. 2009, 72, 1761-1767. doi:10.1021/np900268z
21. Trisuwan, K.; Rukachaisirikul, V.; Sukpondma, Y.; Phongpaichit, S.; Preedanon, S.; Sakayaroj, J. Tetrahedron 2010, 66, 4484-4489. doi:10.1016/j.tet.2010.04.073

22. Kohno, J.; Sakurai, M.; Kameda, N.; Nishio, M.; Kawano, K.; Kishi, N.; Okuda, T.; Komatsubara, S. J. Antibiot. 1999, 52, 913-916. doi:10.7164/antibiotics.52.913

23. Chen, S.; Liu, Y.; Liu, Z.; Cai, R.; Lu, Y.; Huang, X.; She, Z. RSC Adv. 2016, 6, 26412-26420. doi:10.1039/C6RA02566H

24. Wang, P.-P.; Zhao, G.-W.; Xia, W.; Han, E.-J.; Xiang, L. Chin. J. Nat. Med. 2014, 12, 377-381. doi:10.1016/S1875-5364(14)60047-9

25. Jiao, Z.-Z.; Yue, S.; Sun, H.-X.; Jin, T.-Y.; Wang, H.-N.; Zhu, R.-X.; Xiang, L. J. Nat. Prod. 2015, 78, 2588-2597. doi:10.1021/acs.jnatprod.5b00524

\section{License and Terms}

This is an Open Access article under the terms of the Creative Commons Attribution License (http://creativecommons.org/licenses/by/4.0), which permits unrestricted use, distribution, and reproduction in any medium, provided the original work is properly cited.

The license is subject to the Beilstein Journal of Organic Chemistry terms and conditions: (http://www.beilstein-journals.org/bjoc)

The definitive version of this article is the electronic one which can be found at: doi:10.3762/bjoc. 12.196 